\title{
PERANCANGAN APLIKASI PENGELOLAAN ASET BARANG INVENTARIS SDN MAKASAR O5 PAGI JAKARTA TIMUR
}

\author{
Muhamad Nur Witama \\ Program Studi Informatika, Universitas Indraprasta PGRI \\ nur.witama@kumparan.com
}

\begin{abstract}
Abstrak
Teknologi informasi yang bergerak dalam bidang pengelolaan aset atau sistem informasi manajemen, aset merupakan salah satu sistem yang banyak digunakan oleh perusahaan termasuk sekolahan. SDN Makasar 05 Pagi salah satu sekolah yang belum menggunakan sistem komputerisasi salah satunya pengelolaan aset barang sehingga menyulitkan petugas untuk memberikan informasi secara lengkap dan akurat. Tujuan penelitian ini untuk merancang sebuah sistem aplikasi data aset dan laporan data aset dengan menggunakan bahasa pemrograman java dan metode grounded research untuk melakukan pengumpulan data dan analisis data dalam waktu yang bersamaan. Hasil sistem yang dibangun dapat mempermudah dalam proses pendataan aset sehingga lebih mudah dalam pencarian data yang diperlukan dan dapat membantu kinerja petugas tata usaha sehingga lebih efektif dan efisien.
\end{abstract}

Kata Kunci : Perancangan, Pengelolaan Aset Barang, Inventaris, Java, MySQL

\begin{abstract}
Information technology which is engaged in asset management or asset management information systems is one system that is often used by companies including schools. SDN Makasar 05 Pagi one of the schools that has not used a computerized system, one of which is the management of goods assets, making it difficult for officers to provide complete and accurate information. The purpose of this study is to design an asset data application system and asset data report using java programming language and grounded research methods. The results of the system built can facilitate the process of data collection so that it is easier to find the data needed and can help the performance of administrative officers so that it is more effective and efficient.
\end{abstract}

Key Words : Designing, Managing assets, Inventory, Java, MySQL

\section{PENDAHULUAN}

\section{Latar Belakang}

Implementasi Sistem Pengelolaan

Manajemen Aset pada hakekatnya adalah upaya untuk tertib dokumen dan tertib administrasi. Tertib dokumen aset berkaitan dengan upaya penyediaan dan pendataan data-data atau dokumen yang menyertai keberadaan aset, sedangkan tertib administrasi lebih dimaksudkan pada upaya membangun prosedur pengelolaan aset mulai saat pengadaan, penerimaan, perubahan data, hingga penghapusan aset. Bagi sekolah pengelolaan aset sekolah sangatlah penting. Pengelolaan aset sekolah yang baik tentunya dapat meningkatkan kualtitas pendidikan. Berdasarkan Permendagri Nomor 17 Tahun 2007 Pasal 4 Ayat 2 [5] menyatakan bahwa pengelolaan aset atau barang daerah meliputi perencanaan kebutuhan dan penganggaran, pengadaan, penerimaan, penyimpanan dan penyaluran, penggunaan, penatausahaan, pemanfaatan, pengamanan dan pemeliharaan, penilaian, penghapusan, pemindahtanganan, pembinaan, pengawasan dan pengendalian, pembiyaan, dan tuntutan ganti rugi.

SDN Makasar 05 Pagi merupakan salah satu sekolah negeri yang berada di $\mathrm{Jl}$. Pusdiklat RT. 010/005 Kelurahan Makasar Jakarta Timur. Permasalahan yang terdapat pada SDN Makasar 05 Pagi Jakarta Timur yaitu untuk pengolahan data aset barang yang belum menggunakan sistem khusus yang terkomputerisasi, salah satunya pengelolaan aset barang dalam hal ini 
pihak sekolah masih menggunakan sistem manual yaitu pencatatannya masih menggunakan buku besar yang penataannya masih belum teratur sehingga menyulitkan bagi petugas untuk memberikan informasi secara lengkap dan akurat.

Pengelolaan seperti ini menyebabkan kurang maksimalnya pengelolaan data dan pelaporan aset yang ada. Beberapa masalah yang terjadi yaitu sulitnya bagian sarana dan prasarana dalam proses pembuatan laporan manajemen aset. Pembuatan laporan membutuhkan waktu yang cukup lama karena petugas harus mengecek kembali data barang tersedia dan data kondisi barang yang sudah rusak maupun membutuhkan maintenance dengan membuka kembali berkas-berkas yang ada. Resiko kehilangan data pun cukup tinggi, hal ini dikarenakan setelah melakukan pencatatan data barang di buku, petugas biasanya tidak langsung menginputkannya ke dalam komputer. Akibatnya jika terjadi kehilangan buku maka hilang pula semua data aset yang ada. Maka perlu adanya suatu sistem terkomputerisasi pengelolaan data aset sekolah yang terdapat di SDN Makasar 05 Pagi Jakarta Timur.

\section{Tujuan Penelitian}

Untuk merancang dan membuat sebuah sistem aplikasi pengelolaan aset barang pada SDN Makasar 05 Jakarta Timur yang awalnya masih menggunakan proses manual menjadi sebuah sistem yang lebih cepat, modern, dan lebih mudah dalam penggunaannya dengan menggunakan bahasa pemrograman Java.

\section{Manfaat Penelitian}

Manfaat yang diharapkan akan diperoleh dari penelitian ini adalah sebagai berikut: Penelitian ini memberikan manfaat untuk peneliti yaitu menambah pengetahuan dan wawasan baik teori maupun praktek melalui sistem pengelolaan aset barang; dan Memberikan kemudahan serta dapat mempercepat dalam proses pendataan aset dan laporan data aset.

\section{METODE PENELITIAN}

\section{Rancangan Sistem}

Rancangan sistem bertujuan untuk merancang aplikasi yang akan dibuat agar dapat diimplementasikan dengan kebutuhan pengguna yaitu SDN Makasar 05 Pagi Jakarta Timur.

\section{Teknik Pengumpulan Data}

Penelitian ini menggunakan metode grounded research yang bertujuan untuk mengetahui proses perancangan sistem pengelolaan barang yang dilakukan selama ini. Teori. Grounded Research adalah sebuah metodologi penelitian kualitatif yang menekankan penemuan teori dari daata observasi empirik di lapangan dengan metode induktif (menemukan teori dari sejumlah data), generatif yaitu penemuan atau konstrukti teori menggunakan data sebagai evidensi, konstruktif menemukan konstruksi teori atau kategori lewat analisis dan proses mengabstraksi, dan subjektif, yaitu merekonstruksi penafsiran dan pemaknaan hasil penelitian berdasarkan konseptualisasi masyarakat yang dijadikan subjek studi [7].

Tujuan pertama adalah untuk merasionalisasi teori yang didasarkan, diproses, dan dikembangkan melalui kegiatan pengolahan data selama penelitian proses berlangsung. Kedua, merumuskan logika dan karakteristik grounded theory sedangkan tujuan ketiga adalah untuk melegitimasi penelitian kualitatif [1]. Dengan metode ini, penulis melakukan pengumpulan data dan analis data dalam waktu yang bersamaan. Sehingga perancangan aset barang yang dibuat berdasarkan fakta yang ada di lapangan. Data yang dikumpulkan dengan kebutuhan sistem yang akan dirancang. 
Metode pengumpulan data yang dilakukan oleh penulis untuk mendapatkan data-data serta informasi untuk mendukung penyempurnaan hasil dari penelitian ini antara lain:
a.. Studi Kepustakaan
b. Studi Lapangan
c.. Teknik Observasi
d. Dokumentasi

\section{Langkah-Langkah Sistem}

Pengembangan

Adapun langkah-langkah dalam pengembangan perancangan sistem informasi pengelolaan barang pada SDN Makasar 05 Pagi Jakarta Timur sebagai berikut:

\section{Analisa Kebutuhan Sistem}

Analisa sistem dapat diartikan sebagai suatu proses untuk memahami sistem yang ada, dengan menganalisa jabatan dan uraian tugas (business users), proses bisnis (business process), ketentuan atau aturan (business rule), masalah dan mencari solusinya (business problem and business solution), dan rencana-rencana perusahaan (business plan) [10].

Proses perancangan sistem informasi manajemen aset dimulai dari memahami perancangan dan penggunaan. Sebelum merancang sebuah sistem kita harus memahami kebutuhan pengguna. Langkahlangkah yang dilakukan pada tahap ini adalah:

a. Menentukan profil pengguna.

b. Menganalisa task-task yang digunakan.

c. Data masukan.

d. Menganalisa proses yang sedang berjalan atau proses yang sedang digunakan.

e. Mengumpulkan kebutuhan-kebutuhan pengguna.

f. Mencocokkan kebutuhan tersebut dengan task.

\section{Studi Kepustakaan}

Penulis melakukan studi kepustakaan berdasarkan referensi dan berbagai diskusi pembahasan dengan orang yang berkompeten dalam bidang ini. Studi kepustakaan bertujuan memahami dasar teori yang berhubungan dengan analisa kebutuhan yang telah dilakukan.

\section{Perancangan sistem}

Perancangan sistem bertujuan untuk merancang aplikasi yang akan dibuat agar dapat diimplementasikan dengan kebutuhan pengguna. Perancangan Sistem merupakan keseluruhan rencana atau model untuk sistem yang terdiri dari semua spesifikasi sistem yang memberikan bentuk dan struktur [4]. Adapun langkahlangkah yang dilakukan dalam perancangan sistem informasi aset ini adalah:

a. Merancang antarmuka.

b. Merancang Basis Data.

c. Mengembangkan antarmuka.

d. Melakukan validasi terhadap antarmuka.

\section{Implementasi dan Pengkodean}

Pada proses ini penulis mencoba mensimulasikan atau mengimplementasikan dari aplikasi yang sudah dirancang. Penulis juga melakukan dokumentasi dari tahapan yang telah dilalui. Evaluasi yang ditunjukkan sebagai bagian dari tahap terakhir perancangan sistem biasanya dimaksudkan untuk pembahasan. Evaluasi dilakukan di setiap tahap. Kerja sistem biasanya berulang, ketika penulis menyelesaikan satu tahap pengembangan sistem akan berlanjut ke tahap berikutnya, penemuan suatu masalah bisa memaksa penulis kembali ke tahap sebelumnya dan memodifikasinya. Karena selama tahap pengujian, bisa ditemukan program tidak dapat berjalan sebagaimana mestinya, bisa disebabkan kodenya salah untuk mendukung bagian perancangan sistem tertentu atau desainnya tidak lengkap.

Tahap pengkodean dilakukan saat penggunaan bahasa pemrograman java dan menghubungkan data-data yang telah dibuat ke dalam rancangan form. Dengan sistem pengkodean ini diharapkan query 
yang telah dibuat sedemikian rupa dapat dikoneksikan dengan rancangan layar yang ada.

\section{Pengujian Sistem}

Suatu proses untuk memastikan apakah semua fungsi sistem bekerja dengan baik dan mencari apakah masih ada kesalahan pada sistem. Pengujian sangat penting untuk dilakukan untuk menjamin kualitas software dan juga menjadi peninjauan terakhir terhadap spesifikasi, desain dan pengkodean.

\section{Evaluasi Sistem}

Evaluasi yang ditujukan sebagai bagian dari tahap terakhir perancangan sistem biasanya dimaksudkan untuk pembahasan. Evaluasi dilakukan di setiap tahap. Kerja sistem biasanya berulang, ketika menyelesaikan satu tahap pengembangan sistem akan berlanjut terhadap berikutnya. Penemuan suatu masalah bisa memaksa kembali terhadap sebelumnya dan memodifikasinya. Karena selama tahap pengujian, bisa ditemukan program tidak dapat berjalan sebagaimana mestinya, bisa disebabkan kodenya salah untuk mendukung bagian perancangan sistem tertentu atau desainya tidak lengkap.

\section{Mengambil Kesimpulan}

a. Apakah fungsi yang terdapat pada aplikasi perancangan pengelolaan aset barang di SDN Makasar 05 Pagi Jakarta Timur dapat berfungsi sebagai mana yang dimaksud.

b. Apakah sistem pengelolaan aset barang di SDN Makasar 05 Pagi Jakarta Timur yang dibuat sudah dapat memenuhi kebutuhan untuk suatu proses pekerjaan yang berkenan dengan sistem pengelolaan aset barang.

\section{HASIL DAN PEMBAHASAN Diagram Alir Data (DAD) Sistem yang Berjalan \\ Data Flow Diagram (DFD) atau dalam bahasa Indonesia menjadi Diagram Alir}

Data (DAD) adalah representasi grafik yang menggambarkan aliran informasi dan transformasi informasi yang diaplikasikan sebagai data yang mengalir dari masukan (input) dan keluaran (output) [6].

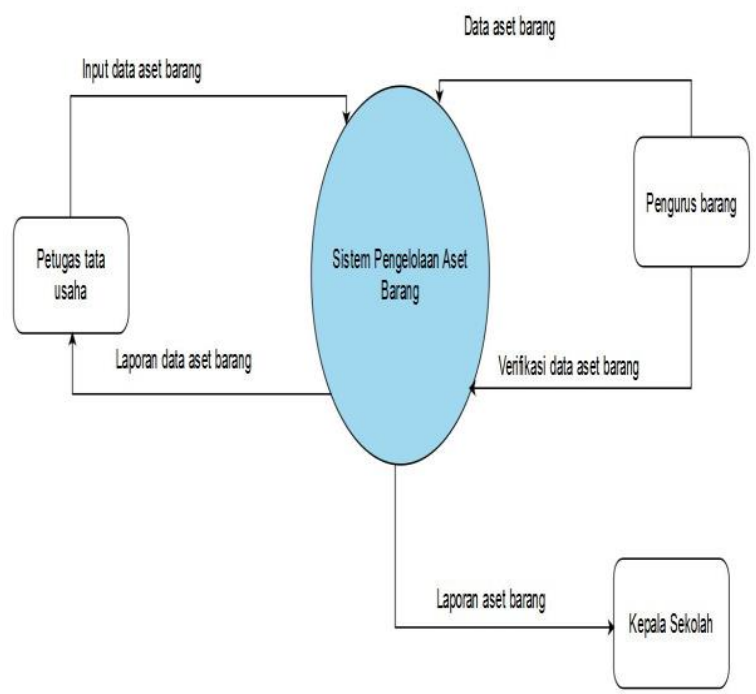

Gambar 1. Diagram Konteks Sistem Berjalan

Dari hasil penelitian yang penulis lakukan, maka dapat diambil beberapa masalah yang dapat diuraikan sebagai berikut:

1. Data aset masih belum terkomputerisasi karena masih menggunakan cara manual

2. Belum adanya Aplikasi Aset Barang yang memudahkan petugas tata usaha dalam melakukan pengelolaan aset barang.

\section{Alternatif Penyelesaian Masalah}

Untuk menyelesaikan beberapa permasalahan diatas, maka diusulkanlah beberapa alternatif untuk menyelesaikan masalah tersebut diantaranya :

1. Sistem manual pengelolaan data aset sekolah diubah menjadi sistem yang terkomputerisasi.

2. Pembuatan aplikasi ini diharapkan akan mempermudah dalam pengelolaan data aset. 
Diagram Alir Data (DAD) Sistem yang Diusulkan

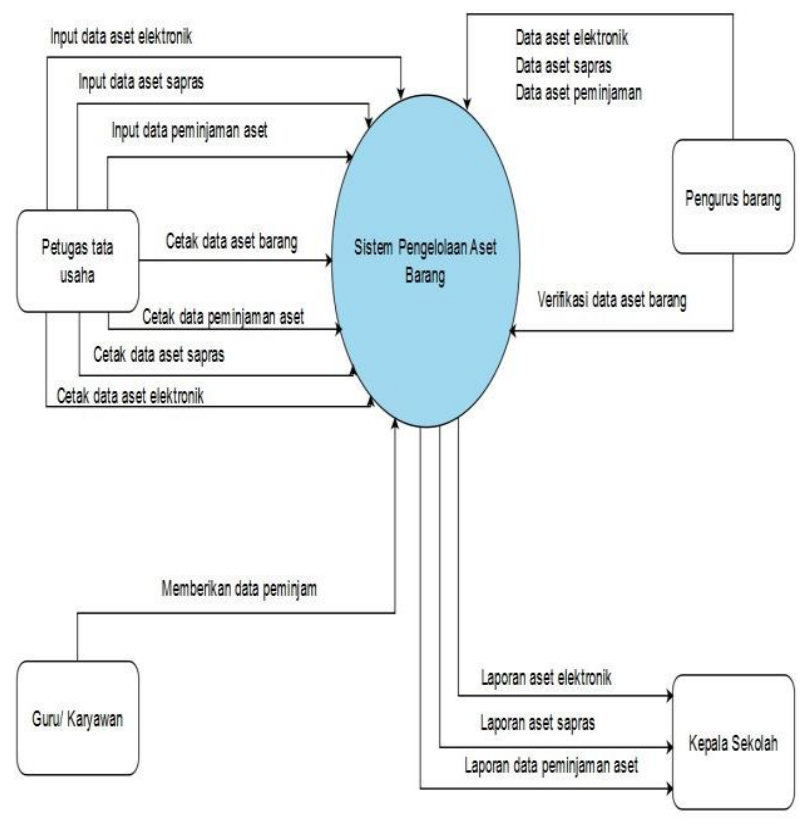

Gambar 2. Diagram Konteks Sistem yang Diusulkan

Perancangan Aplikasi Pengelolaan Aset Barang Inventaris SDN Makasar 05 Pagi Jakarta Timur Berbasis Java Netbeans dan MySQL

Perancangan aplikasi pengelolaan aset barang inventaris SDN Makasar 05 Pagi Jakarta Timur dibangun dengan bahasa pemrograman Java. Java adalah bahasa pemrograman network friendly (yang bisa mudah berpadu dengan suatu jaringan) yang dibangun oleh Sun Microsystems yang digunakan untuk membangun sistem yang besar dan kompleks yang melibatkan beberapa komputer berbeda [8].
Rancangan Layar

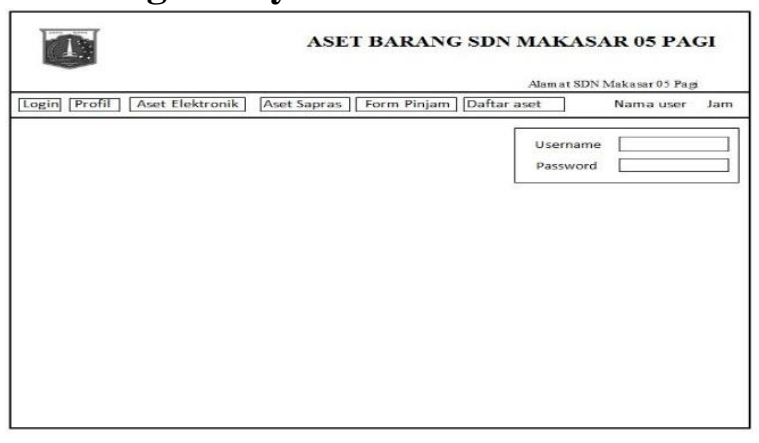

Gambar 3. Rancangan Form Login

\section{Rancangan Menu Utama}

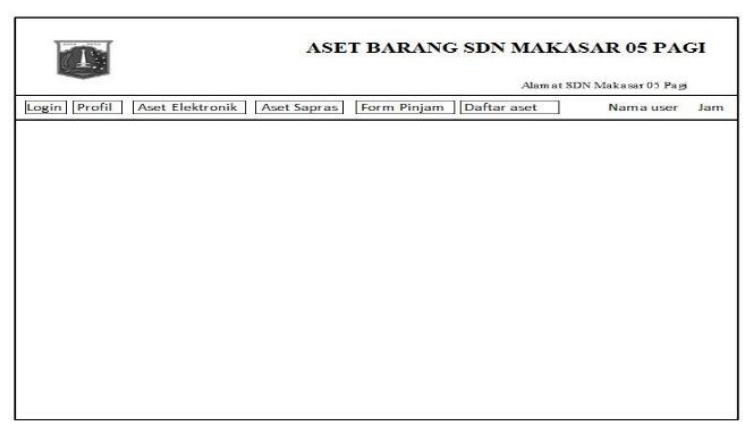

Gambar 4. Rancangan Form Menu Utama

\section{Rancangan Menu Profil}

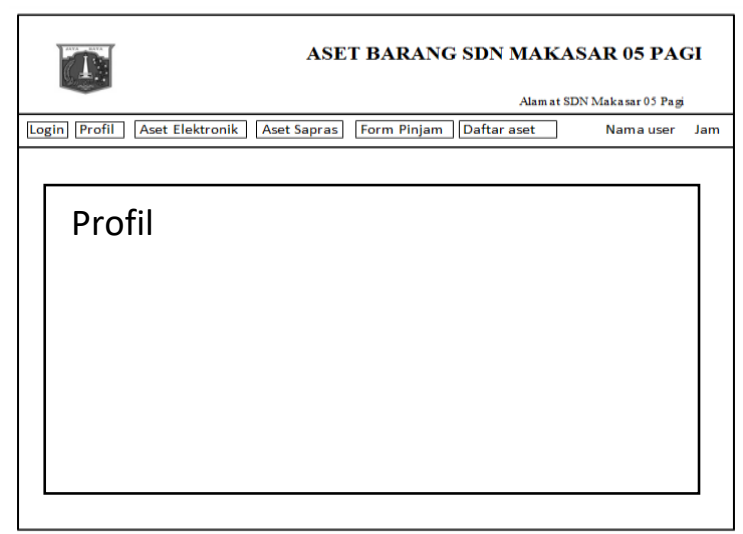

Gambar 5. Rancangan Form Menu Profil 
Rancangan Menu Inputan Data Aset Elektronik

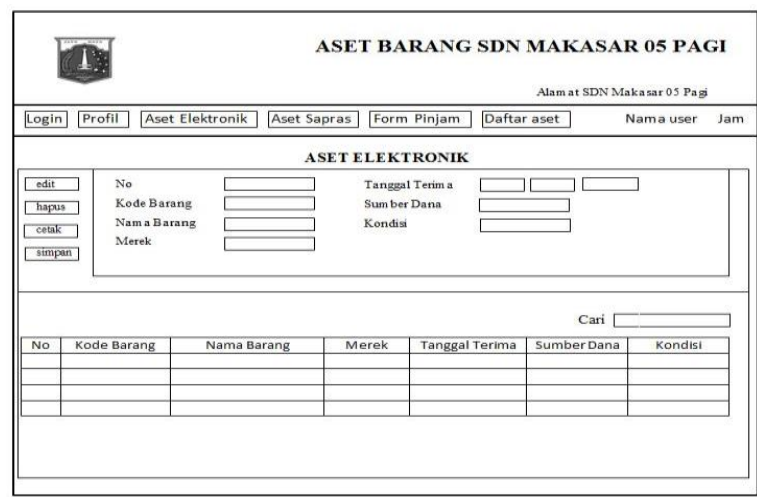

Gambar 6. Rancangan Form Data Aset Elektronik

\section{Rancangan Menu Inputan Data Aset} Sapras

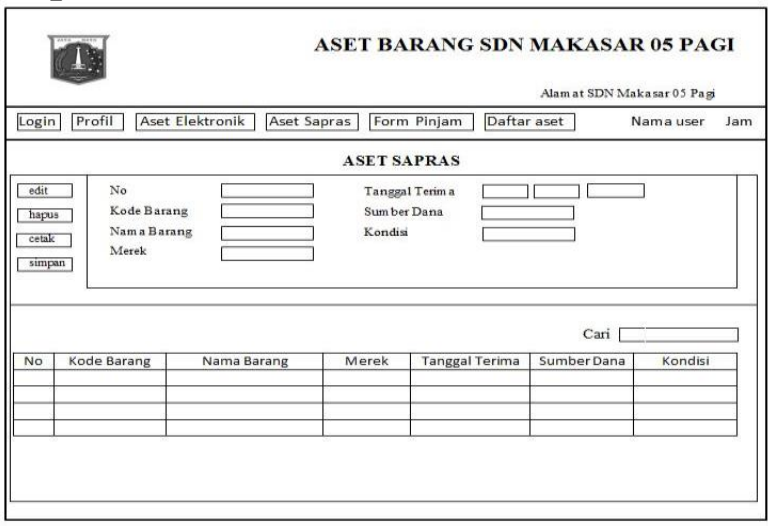

Gambar 7. Rancangan Form Data Peminjaman Aset

Rancangan Form Daftar Aset Elektronik

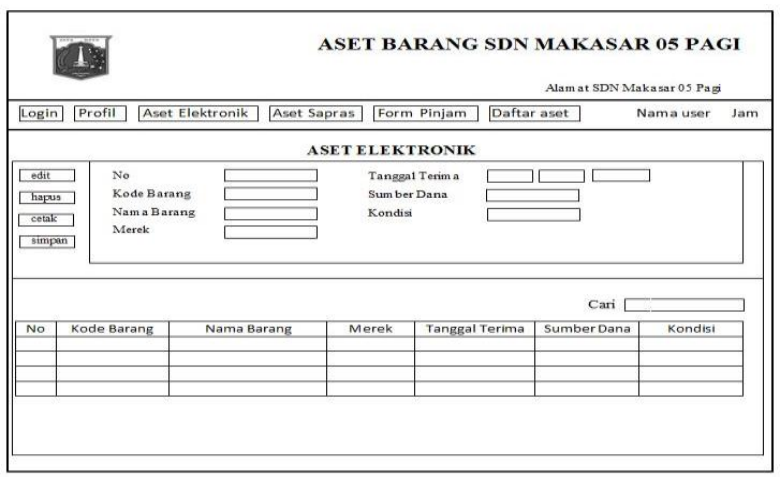

Gambar 8. Rancangan Form Daftar Aset Elektronik

\section{Rancangan Form Daftar Aset Sapras}

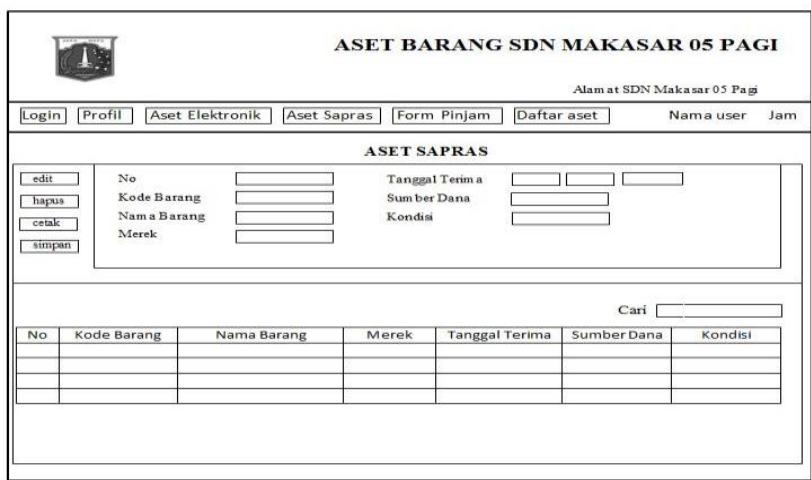

Gambar 9. Rancangan Form Daftar Aset Sapras

Rancangan Form Data Guru dan Karyawan

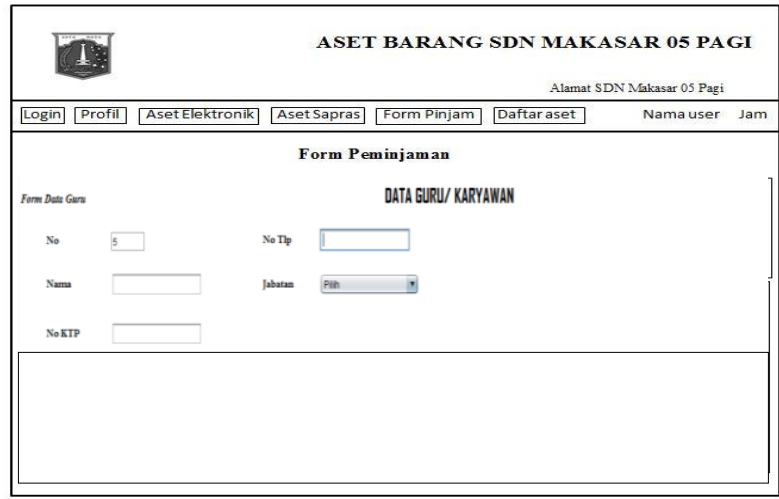

Gambar 10. Rancangan Form Data Guru dan Karyawan

\section{Rancangan Report Aset Elektronik}

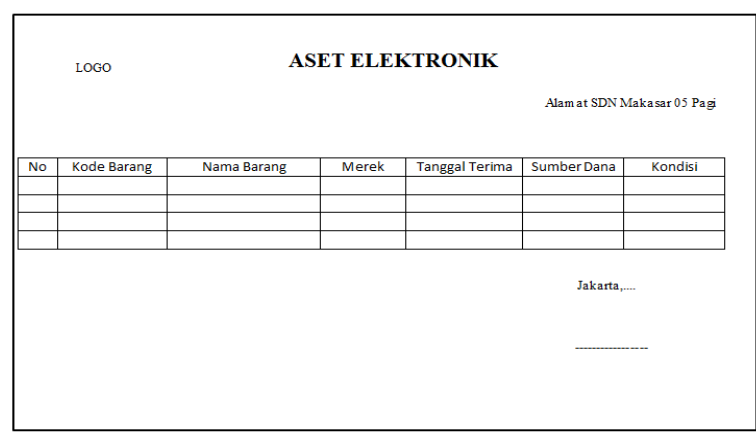

Gambar 11. Rancangan Report Aset Elektronik 


\section{Rancangan Report Aset Sapras}

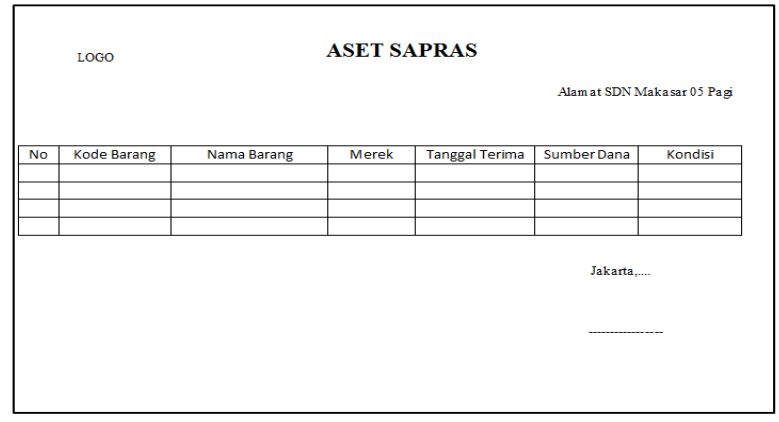

Gambar 12. Rancangan Report Aset Sapras

\section{Rancangan Report Peminjaman}

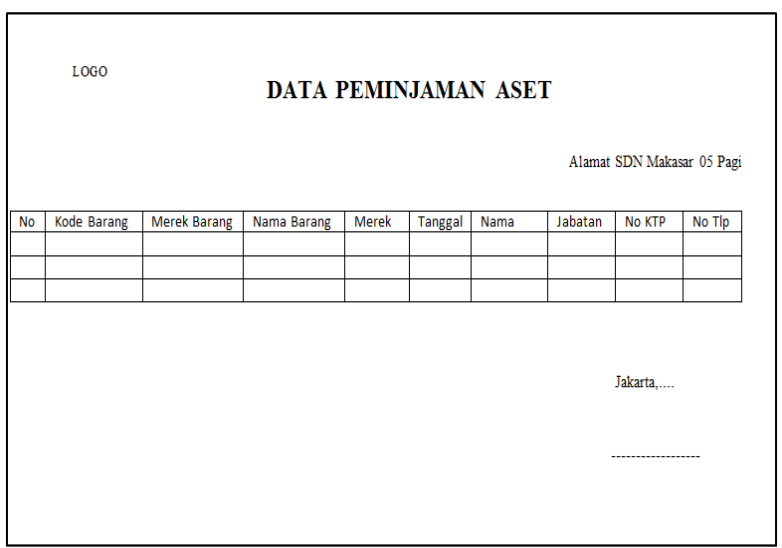

Gambar 13. Rancangan Form Report Peminjaman Aset

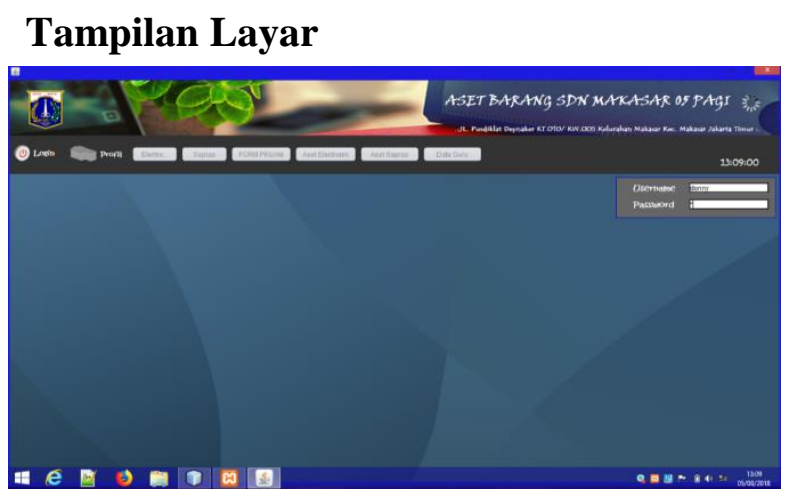

Gambar 14. Tampilan Form Login

Tampilan di atas terdapat pada awal program. Menu login digunakan sebagai kata kunci sebelum kita memasuki program utama. Agar tidak ada orang dapat mengakses program ini. Sehingga dalam form menu kerahasiannya tetap terjaga dengan baik. Apabila pengguna dapat memasukan kata kunci dengan benar maka tombol menu utama akan aktif dan program siap di gunakan.

\section{Tampilan Layar Menu Utama}

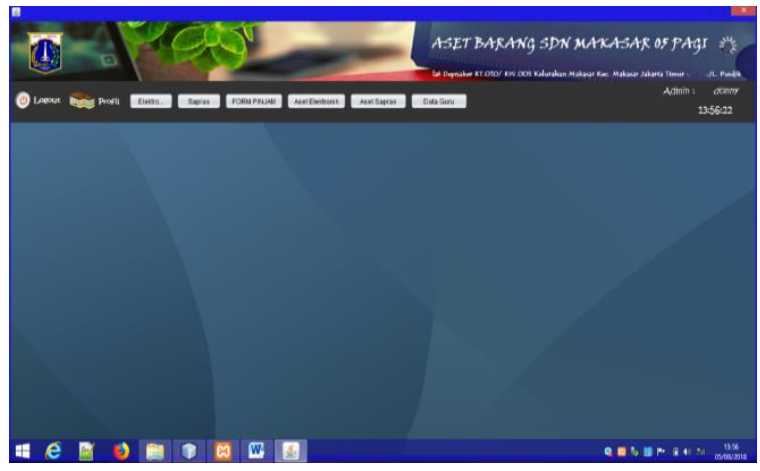

Gambar 15. Tampilan Form Menu Utama

Tampilan di atas menampilkan tampilan menu aplikasi aset barang. Pada layar utama tersedia beberapa menu yang terdiri dari menu aset elektronik, menu aset sapras, menu form pinjam, daftar aset elektronik, daftar aset sapras dan data guru.

Tampilan Layar Menu Form Aset Elektronik

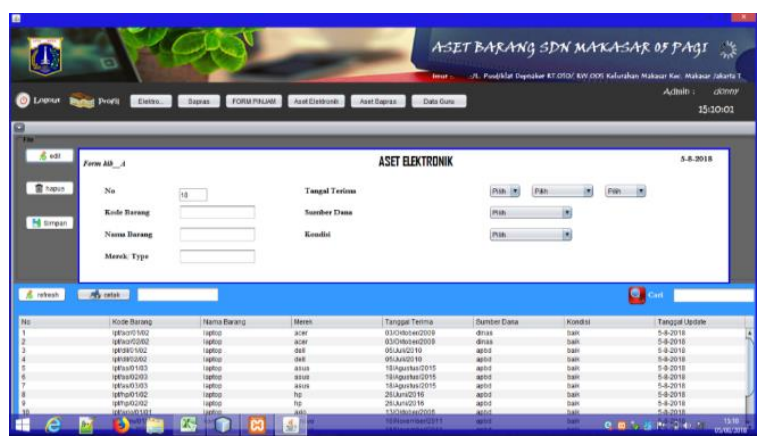

\section{Gambar 16. Tampilan Form Aset Elektronik}

Pada tampilan di atas merupakan tampilan form Data aset elektronik. Form ini memiliki beberapa tombol yang terdiri dari tombol simpan berfungsi untuk menyimpan data aset baru, tombol hapus untuk menghapus data aset, tombol edit 
untuk merubah data pada aset barang, tombol refresh untuk mengurutkan kembali nomor setelah salah satu data di hapus, tombol cari untuk mencari data, sedangkan tombol cetak digunakan untuk mencetak data aset.

\section{Tampilan Layar Menu Form Aset Satpras}

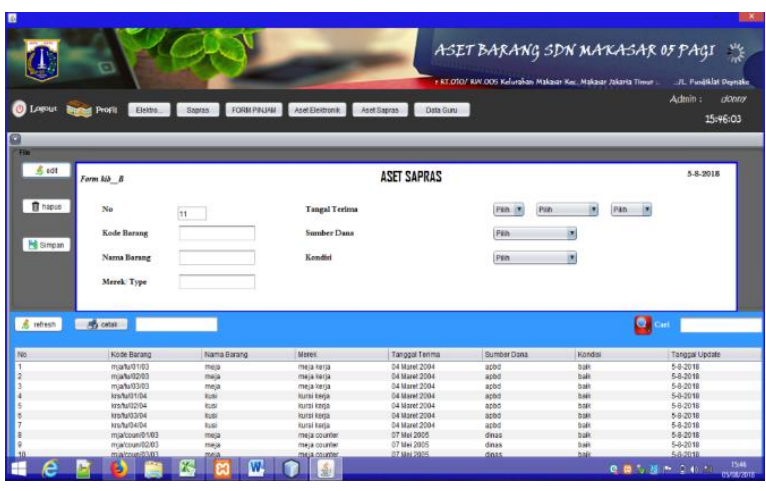

Gambar 17. Tampilan Form Aset Satpras

Tampilan di atas merupakan tampilan form Data aset sapras. Form ini memiliki beberapa tombol yang terdiri dari tombol simpan berfungsi untuk menyimpan data aset baru, tombol hapus untuk menghapus data aset, tombol edit untuk merubah data pada aset barang, tombol refresh untuk mengurutkan kembali nomor setelah salah satu data di hapus, tombol cari untuk mencari data aset, sedangkan tombol cetak digunakan untuk mencetak data aset.

\section{Tampilan Menu Form Peminjaman Aset}

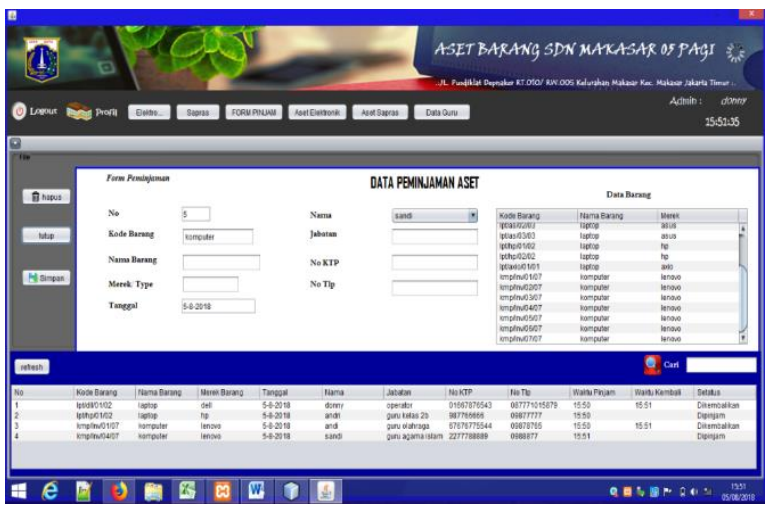

Gambar 18. Tampilan Form Peminjaman Aset
Tampilan di atas merupakan tampilan form Data aset sapras. Form ini memiliki beberapa tombol yang terdiri dari tombol simpan berfungsi untuk menyimpan data peminjaman aset, tombol hapus untuk menghapus data peminjaman aset, tombol edit untuk merubah data pada peminjaman aset, tombol refresh untuk mengurutkan kembali nomor setelah salah satu data di hapus, tombol cari untuk mencari data aset, sedangkan tombol cetak digunakan untuk mencetak data aset.

\section{SIMPULAN}

Berdasarkan hasil penelitian yang telah dilakukan penulis, maka dapat diambil beberapa kesimpulan yaitu:

1. Sistem yang dibangun ini dapat mempermudah dalam proses pendataan aset barang, sehingga lebih mudah dalam pencarian data yang diperlukan.

2. Dengan dibuatnya sistem pengelolaan aset barang inventaris ini diharapkan dapat membantu kinerja petugas tata usaha sehingga lebih efektif dan efisien.

\section{UCAPAN TERIMAKASIH}

Terimakasih kami ucapkan SDN Makasar 05 Pagi Jakarta Timur yang telah memberikan bantuan sehinga penelitian ini dapat terlaksana dengan baik.

\section{DAFTAR PUSTAKA}

[1] Denzin, Norman K \& Lincoln, Yvonna S. Handbook of Qualitative Research. California: Sage Publication. 2000.

[2] Dewi, S., Jannah L.M., Jumaryadi, Y. Analisis dan Perancangan Sistem Informasi Manajemen Aset Tetap Pada PT. Metis Teknologi Corporindo. Jurnal Sistem Informasi, Teknologi Informasi dan Komputer (JUST IT). Vol. 9. No.1 2018. 
[3] Kalangi Dita Yolinita L.C., Kalangi Lintje, Warongan D. L. Jessy. Analisis Pengelolaan Barang Milik Daerah di Kabupaten Minahasa Utara. Jurnal Riset Akuntansi Going Concern 12 (2). 123-130. 2017.

[4] Laudon, Kenneth C., \& Jane, P. Laudon. Management Information System: Managing the Digital Firm. New Jersey: Prentice-Hall. 2010.

[5] Nugroho, Dwi Hendy. Pengembangan Sistem Informasi Inventaris Barang Berbasis Website di SMK PIRI 2 Yogyakarta. Tugas Akhir Skripsi Program Studi Pendidikan Teknik Informatika Fakultas Teknik: UNY. 2018.
[6] R. A. Sukamto dan M. Shalahuddin. Rekayasa Perangkat Lunak. Bandung: Informatika. 2013.

[7] Sudira, P., Studi Mandiri Grounded Theory. Yogyakarta: UNY. 2009.

[8] Untara, Wahyu. Kamus Sains. Ed. Nunggal Seralati H., Ed. Noviadewi ayusari. Yogyakarta: Indonesia Tera. 2014.

[9] Peraturan Menteri Dalam Negeri Nomor 17 Tahun 2007 Pasal 4 ayat 2 [5] tentang Pedoman Teknis Pengelolaan Barang Milik Daerah.

[10] Yakub. Pengantar Sistem Informasi. Graha Ilmu. 2012. 